Eur. J. Clin. Chem. Clin. Biochem.

Vol. 30, 1992, pp. $27-32$

(C) 1992 Walter de Gruyter \& Co.

Berlin · New York

\title{
Sensitive Amplified Immunoenzymometric Assays (IEMA) for Human Insulin and Intact Proinsulin
}

\author{
By Beatrice Alpha ${ }^{1}$ ), Lorna Cox, N. Crowther, Penelope M. S. Clark and C. N. Hales \\ Department of Clinical Biochemistry, University of Cambridge, Addenbrooke's Hospital, Cambridge, UK
}

(Received June 25/November 4, 1991)

Summary: Immunoenzymometric assays (IEMAs) for human insulin and intact proinsulin were developed using the amplification system developed by Johannsson et al. (Clin. Chim. Acta 148 (1985) 119-124) for the detection of the enzyme alkaline phosphatase. The detection limit of the assays was $0.8 \mathrm{pmol} / 1$ for proinsulin and $0.8 \mathrm{pmol} / 1$ for insulin whereas it was $1.8 \mathrm{pmol} / \mathrm{l}$ and $2.3 \mathrm{pmol} / \mathrm{l}$ respectively for the homologous immunoradiometric assays (IRMA). These assays are superior to immunoradiometric assays in terms of sensitivity, shelf-life of the labelled antibody and suitability for automation.

\section{Introduction}

We have established new monoclonal antibody based two-site immunoradiometric assays (IRMAs) specific for insulin, proinsulin, $32-33$ split and $65-66$ split proinsulins (1). These assays have provided new information concerning the changes of insulin and proinsulin in Type II diabetes (2). However, the sensitivity of the immunoradiometric assay is barely adequate for the accurate determination of intact proinsulin in plasma from fasting normal subjects. In addition, assays based upon the use of ${ }^{125}$ I as an antibody label and cellulose solid phase are not ideal for the analysis of large numbers of samples. In order to

\footnotetext{
1) Funding organisations:

French Fondation pour la Formation par la Recherche a l'Interface Chimie-Biologie Paris, France

Medical Research Council, London

British Diabetic Association, London

2) Enzymes:

Alcohol dehydrogenase, alcohol: $\mathrm{NAD}^{+}$oxidoreductase EC 1.1.1.1

Alkaline phosphatase, orthophosphoric-monoester phosphohydrolase EC 3.1.3.1.

Diaphorase, dihydrolipoamide: $\mathrm{NAD}^{+}$oxidoreductase EC 1.8.1.4

Horse radish peroxidase, donor: hydrogen-peroxide oxidoreductase EC 1.11.1.7
}

avoid the frequent iodinations necessitated by the use of ${ }^{125}$ I-labelled reagents immunoenzymometric assays (IEMAs) have been developed using an alkaline phosphatase-labelled monoclonal antibody and an amplification system for measurement of the label.

Several methods have been published for labelling antibodies with alkaline phosphatase $\left.{ }^{2}\right)(3,4)$. Conjugation has been carried out using glutaraldehyde as a homobifunctional reagent. However, this method has the disadvantage of producing highly polymerised, heterogenous conjugates (5). To overcome this problem we have used a heterobifunctional conjugation reagent, $\mathrm{N}$-succinimidyl-3-(2-pyridyldithio)-propionate. The reaction of this compound with proteins is more easily controlled than that of glutaraldehyde, and more sensitive assays have been obtained using antibody-horse radish peroxidase $\left.{ }^{2}\right)$ conjugates prepared with N-succinimidyl-3-(2-pyridyldithio)-propionate as compared with glutaraldehyde. The principle of the $\mathrm{N}$-succinimidyl-3-(2-pyridyldithio)-propionate conjugation is to introduce 2-pyridyl-disulphide groups into proteins. One of the proteins is then thiolated by reduction of the 2-pyridyl-disulphide groups with a reducing agent. 2-Pyridyl-disulphide groups on one protein and exposed aliphatic thiol groups on the other are then allowed to react to form the conjugate. 
By varying the $\mathrm{N}$-succinimidyl-3-(2-pyridyldithio)propionate/protein and the alkaline phosphatase/protein ratio different conjugates were obtained as shown in the first part of our study. In the second part we report the results obtained in the IEMAs of human insulin and intact proinsulin. Two monoclonal antibodies were used for each assay, one of them labelled as described with alkaline phosphatase and the other coated to a microtitre plate. An enzyme amplification step was used to obtain a sensitivity greater than that observed in the immunoradiometric assay. In this system $\beta$-nicotinamide adenine dinucleotide phosphate, reduced form (NADPH) was first converted to $\beta$-nicotinamide adenine dinucleotide (NADH) by alkaline phosphatase. The NADH was then used as a cofactor in a cyclic reaction involving the enzymes diaphorase and alcohol dehydrogenase to alternately oxidize and reduce the cofactor in parallel with the reduction of a dye $(8,9)$.

\section{Materials and Methods}

Materials

Human insulin standard was the first IRP (International reference preparation) coded 66/304. Intact human proinsulin was supplied by Lilly Research Laboratories, Indianapolis, Indiana 46285, USA (1). F-16 Immuno Module, flat bottom polystyrene microtitre plates were obtained from Nunc (Roskilde, Denmark). Calf intestine alkaline phosphatase was obtained from Biozyme Laboratories (Blaenavon, Gwent) as a glycerol solution containing sodium phosphate $(50 \mathrm{mmol} / \mathrm{l}, \mathrm{pH} 6.5), \mathrm{MgCl}_{2}$ $(5 \mathrm{mmol} / \mathrm{l})$ and $\mathrm{ZnCl}_{2}(0.1 \mathrm{mmol} / \mathrm{l})$, and used without further purification. The heterobifunctional reagent N-succinimidyl-3(2-pyridyldithio)-propionate was from Pharmacia (Uppsala, Sweden). Diaphorase from pig heart was obtained from Boehringer Mannheim (Lewes, E Sussex, UK). All other chemicals and solvents were obtained from Sigma Chemical Co (Poole, Dorset, UK) or BDH (Poole, Dorset, UK).

Monoclonal antibodies 3B1, 14B and A6 were prepared as described elsewhere (1). The IgG fraction used was prepared from the ascites fluid by precipitation with saturated ammonium sulphate $(400 \mathrm{~g} / \mathrm{l})$ and affinity chromatography on DEAE Affigel Blue (10) or an Hydroxylapatite column (11). The purity of monoclonal antibodies was assessed by electrophoresis on a $10 \%$ sodium dodecyl sulphate polyacrylamide gel (SDS PAGE). The only protein bands visualized after staining with Coomassie Brilliant Blue were those of the IgG light and heavy chains.

Buffers (see table 1)

\section{Tab. 1. Buffers used}

A Sodium phosphate, $0.1 \mathrm{~mol} / 1, \mathrm{pH} 7.5 ; 0.1 \mathrm{~mol} / 1 \mathrm{NaCl}$

B Sodium acetate, $0.1 \mathrm{mmol} / 1$

C Triethanolamine, $0.1 \mathrm{~mol} / \mathrm{l}, \mathrm{pH} 7.0 ; 0.1 \mathrm{~mol} / 1 \mathrm{NaCl}$, $1 \mathrm{mmol} / 1 \mathrm{MgCl}_{2}, 0.1 \mathrm{mmol} / 1 \mathrm{ZnCl}_{2}, 3 \mathrm{mmol} / 1 \mathrm{NaN}_{3}$

E Tris, $0.01 \mathrm{~mol} / \mathrm{l}, \mathrm{pH} 8.5 ; 0.1 \mathrm{~mol} / 1 \mathrm{NaCl}, 3 \mathrm{mmol} / 1 \mathrm{NaN}_{3}$

F Sodium barbitone/ $\mathrm{HCl}, 0.05 \mathrm{~mol} / \mathrm{l}, \mathrm{pH} 8.0 ; 0.09 \mathrm{~mol} / \mathrm{l}$ $\mathrm{NaCl}, 0.015 \mathrm{~mol} / 1 \mathrm{NaN}_{3}, 73 \mu \mathrm{mol} / \mathrm{l}$ bovine serum albumin

\section{Conjugation method}

a) Derivatization of the enzyme

To a solution of alkaline phosphatase $(3.9 \mathrm{~g} / \mathrm{l})$ in buffer A was added a known molar excess of $\mathrm{N}$-succinimidyl-3-(2pyridyldithio)-propionate $(10 \mathrm{mmol} / \mathrm{l}$ fresh solution in $\mathrm{ab}$ solute ethanol). Following a reaction period of $30 \mathrm{~min}$ the reaction mixture was subjected to gel filtration using PD-10 Sephadex G-25 (Pharmacia, Uppsala, Sweden) equilibrated in buffer A. The number of 2-pyridyl-disulphide groups coupled was determined by measuring the release of thiopyridone following reduction of the disulphide bond (6).

b) Derivatization of the monoclonal antibodies

To a solution of monoclonal antibody $3 \mathrm{~B} 1(6.4 \mathrm{~g} / \mathrm{l}$ in buffer A) was added the chosen molar excess of $\mathrm{N}$-succinimidyl-3(2-pyridyldithio)-propionate (same $10 \mathrm{mmol} / \mathrm{l}$ solution in absolute ethanol). Following a reaction period of about 30 min the reacting mixture was subjected to gel filtration using PD-10 Sephadex G-25 equilibrated in buffer B. The protein fractions were pooled and the resulting solution concentrated by freeze-drying.

The concentrated solution of modified 3B1 (about $1 \mathrm{~g} / \mathrm{l}$ ) was then treated with a solution of dithiothreitol $(0.5 \mathrm{~mol} / 1$ in buffer B) at a final concentration of $25 \mathrm{mmol} / \mathrm{l}$. The reaction solution was mixed and left at room temperature for 30 min. Excess reagent, oxidized reagent and the product pyridine 2-thione were removed by passing the mixture through the gel filtration PD-10 Sephadex G-25 column using buffer $\mathrm{A}$ as eluent.

\section{c) Protein coupling}

Immediately after the reduction step, the pooled fraction of modified 3B1 monoclonal antibody was added to the one of modified enzyme in a known molar ratio. The resulting solution was further concentrated to about $1.5 \mathrm{~g} / \mathrm{l}$. The reaction time was $18-24 \mathrm{~h}$ at $24^{\circ} \mathrm{C}$. The coupling solution was then passed down a gel filtration column Sephadex G$200(12 \times 1.5 \mathrm{~cm})$ equilibrated in buffer $\mathrm{A}$. The pooled fraction containing conjugated antibody was further purified on a FPLC Superose ${ }^{\mathrm{TM}} 6$ (Pharmacia) column using buffer $\mathrm{C}$ as eluent. The column was run at a flow rate of $0.3 \mathrm{ml} /$ min and $0.5 \mathrm{ml}$ fractions were collected. The fractions containing conjugate were pooled and concentrated.

Protein determinations were performed using the Bio-Rad protein assay (Bio-Rad Laboratories $\mathrm{GmbH}$, W-8000 München 50, Germany). The enzyme activity of the conjugate was measured using $p$-nitrophenyl phosphate as substrate and the antigen binding activity of the conjugate was tested in a two-site assay of insulin (either on microtitre plates or in Eppendorf tubes) as described below. The conjugate was stored at $4{ }^{\circ} \mathrm{C}$ in buffer $\mathrm{A}$ or $\mathrm{C}$ containing bovine serum albumin $(80 \mu \mathrm{mol} / \mathrm{l})$ and $\mathrm{NaN}_{3}(3 \mathrm{mmol} / \mathrm{l})$.

\section{Measurement of enzyme activity}

Alkaline phosphatase activity of column eluate fractions was determined using $p$-nitrophenyl phosphate as substrate (12). The colour development was followed by continuous measurement at $405 \mathrm{~nm}$ using a $\mathrm{V}_{\max }$ computer-controlled microplate reader (Molecular Devices, California).

In the insulin and proinsulin assays the alkaline phosphatase activity was measured using the amplification system $(8,9)$, with the change in absorbance at $490 \mathrm{~nm}$ measured continuously.

\section{Measurement of antigen binding ability}

This was carried out using radiolabelled human insulin (gift from Eli Lilly) and cellulose sheep anti-mouse IgG immunoadsorbent to precipitate the complexes formed between the conjugated monoclonal antibody and insulin (13). 
Immunoenzymometric assays

Microtitre plates were coated with monoconal antibody A6 and $14 \mathrm{~B}$ at 10 or $50 \mathrm{mg} / \mathrm{l}$ respectively in coating buffer E. Monoclonal antibody solution $(200 \mu \mathrm{l}$ per well) was added to the microtitre plate and incubated overnight at $4{ }^{\circ} \mathrm{C}$. The coated strips were then washed three times with $0.5 \mathrm{ml} / 1$ Tween 20 in buffer $\mathrm{E}$, then blocked by incubating with $147 \mu \mathrm{mol} / \mathrm{l}$ bovine serum albumin solution ( $500 \mu \mathrm{l}$ per well) in buffer $\mathrm{E}$ for 1 to $3 \mathrm{~h}$ at room temperature or overnight at $4{ }^{\circ} \mathrm{C}$. The plate was then washed $(400 \mu \mathrm{l}$ per well) twice with buffer $\mathrm{F}$, diluted $1 / 2$ $(\mathrm{v} / \mathrm{v})$ and containing $5 \mathrm{ml} / 1$ Tween 20 , and once in buffer $\mathrm{F}$, diluted $1 / 2(v / v)$. This same washing procedure was used during the assay. The coated wells were stored filled with $300 \mu$ l buffer E at $4{ }^{\circ} \mathrm{C}$.

a) Insulin assay

The assay for human insulin was carried out using alkaline phosphatase-conjugated 3B1 monoclonal antibody in a twostep assay. In this procedure, sample $(25 \mu \mathrm{l})$, mouse serum $(3 \mu \mathrm{l})$ and $735 \mu \mathrm{mol} / 1$ bovine serum albumin buffer $\mathrm{F}(75$ $\mu \mathrm{l})$ were added to $14 \mathrm{~B}$ monoclonal antibody coated wells and incubated overnight at $4{ }^{\circ} \mathrm{C}$. After aspiration of the solution, $100 \mu \mathrm{l}$ conjugate at the appropriate optimum dilution in buffer $F(0.03 \mu \mathrm{g} / \mathrm{l}$ for conjugate IV) was added and incubated overnight at $4{ }^{\circ} \mathrm{C}$. The solution was aspirated and the wells washed (as described previously). The bound enzyme was detected using the amplification system. Standards were diluted in $735 \mu \mathrm{mol} / \mathrm{l}$ bovine serum albumin in buffer $F$.

b) Proinsulin assay

The proinsulin determination was carried out as described above with alkaline phosphatase-conjugated-3B1 monoclonal antibody, but with A6 monoclonal antibody coated wells and using $10 \mu \mathrm{l}$ mouse serum per well.

\section{Immunoradiometric assays}

These assays were carried out as described (1) using plasma samples diluted $1 / 4 \mathrm{v} / \mathrm{v}$ in $735 \mu \mathrm{mol} / \mathrm{l}$ bovine serum albumin in buffer $\mathrm{F}$.

\section{Results}

\section{Conjugate purification}

After conjugation the mixture contained a variety of heteropolymers, free antibody and enzyme. The free antibody competing with the labelled antibody would reduce the sensitivity of the assay, whereas the free enzyme might increase the background reaction. $\mathrm{Pu}$ rification was carried out in FPLC Superose ${ }^{\mathrm{TM}} 6$ column (Pharmacia, Uppsala, Sweden) allowing the separation of the conjugates (relative molecular mass $M_{\mathrm{r}} 250000$ and above) from the starting uncoupled enzyme and antibody (fig. 1).

\section{Variation of conjugation conditions}

The conjugates listed in table 2 have been prepared. The two critical variables of the conjugation process are the molar ratios of 2-pyridyl-disulphide/IgG, 2pyridyl-disulphide/enzyme. 2-Pyridyl-disulphide represents the chemical group introduced by reaction between amino groups on the protein and the $\mathrm{N}$ succinimidyl-3-(2-pyridyldithio)-propionate reagent.

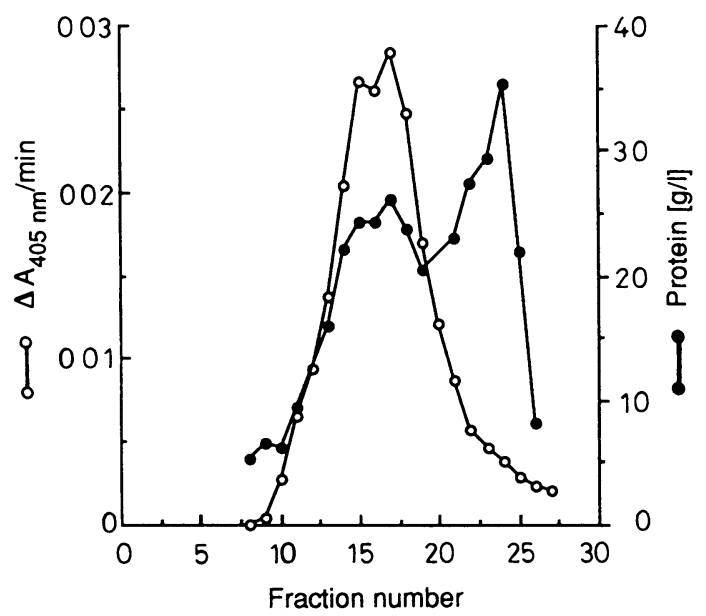

Fig. 1. Fractionation of an alkaline phosphatase-3B1 monoclonal antibody conjugate on a FPLC column of Superose ${ }^{\mathrm{TM}} 6$.

The purification was carried out using buffer $\mathrm{C}$ as eluent. The reading at $405 \mathrm{~nm}$ indicates the amount of enzyme. The unconjugated enzyme and 3B1 monoclonal antibody eluated in fraction No. 23.

Tab. 2. Conjugates prepared

\begin{tabular}{lcclc}
\hline Conjugate & $\begin{array}{l}\text { PDP/ } \\
\text { enzyme }^{(1)}\end{array}$ & $\begin{array}{l}\text { SPDP/ } \\
\text { 3B1 }\end{array}$ & $\begin{array}{l}\text { Enzyme/ } \\
\text { 3B1 }\end{array}$ & $\begin{array}{l}\text { Specific } \\
\text { activity }^{(3)}\end{array}$ \\
\hline I & 2 & 5 & 1.5 & 579.5 \\
II & 22 & 18 & 1.5 & 68.8 \\
III & 6 & 8 & 6 & 207.2 \\
IV & 15 & 16 & 2.4 & 103.4 \\
\hline
\end{tabular}

(1) measured value determined by quantifying the amount of pyridine-2-thione (PDP) released by reduction with dithiothreitol

(2) molar excess of $\mathrm{N}$-succinimidyl-3-(2-pyridyldithio)-propionate (SPDP) used versus the concentration of 3B1 monoclonal antibody

(3) corresponds to the enzyme activity per weight of protein in the conjugate in $\Delta \mathrm{A} / \mathrm{min}$ per $\mathrm{mg}$

The effect of the number of 2-pyridyl-disulphide groups on alkaline phosphatase enzymatic activity and 3B1 monoclonal antibody binding activity is shown in figure 2. It is apparent that introducing more than 15 2-pyridyl-disulphide groups for alkaline phosphatase and 18 for 3B1 monoclonal antibody reduces their respective activity to less than $50 \%$.

The purification profile of the prepared conjugates on the Superose ${ }^{\mathrm{TM}} 6$ column revealed the polydisperse nature of the conjugates. Conjugate IV exhibited a larger range of relative molecular mass. These conjugates were compared in a two-site assay for insulin at a dilution presenting either similar enzymatic activity (fig. 3a) or similar protein content (fig. 3b). In both experiments the polydisperse conjugate IV gave the greatest increase over background. This conjugate 


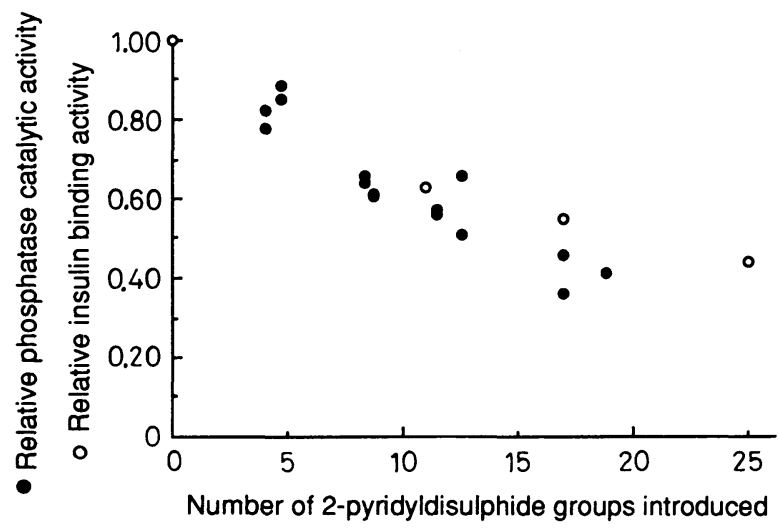

Fig. 2. Effect of N-succinimidyl-3-(2-pyridyldithio)-propionate modification on alkaline phosphatase enzyme activity (closed circles) and 3B1 insulin binding ability (open circles).

Abscissa: number of 2-pyridyl-disulphide groups introduced on the enzyme or monoclonal antibody.

Ordinate: percentage of enzymatic activity measured at $490 \mathrm{~nm}$; percentage of ${ }^{125}$ I-insulin binding activity in the absence of conjugation. The percentage of ${ }^{125}$ I-insulin bound by the conjugated antibody was $51 \%$.
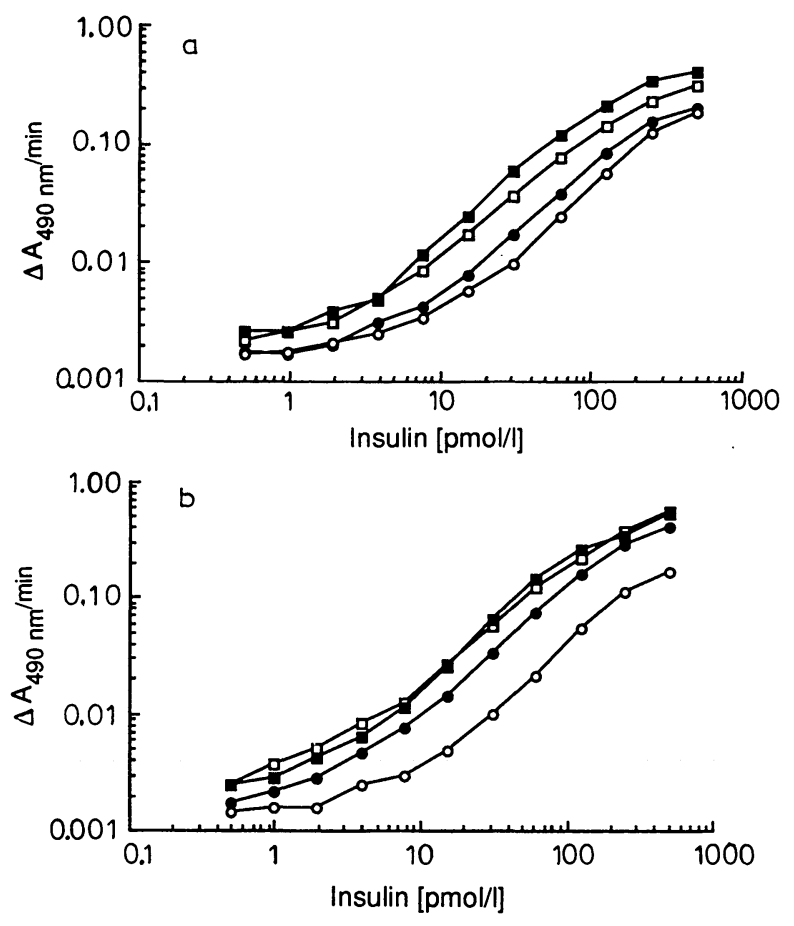

Fig. 3. Standard curves for IEMA of human insulin obtained by using conjugates I to IV (tab. 1) at

(a) similar enzyme activity $(\Delta \mathrm{A} / \mathrm{min}=0.16-0.18)$ for $10 \mu \mathrm{l}$ of conjugate dilution) and

(b) similar protein content $(0.05 \mu \mathrm{g} / \mathrm{l})$.

Conjugate I (open squares), II (open circles), III (closed circles), IV (closed squares).

was used for the IEMAs of human insulin and intact proinsulin. A more precise characterisation and comparison of the different conjugates is very difficult, due to the great heterogeneity of the large molecular weight species and to the inability to determine the ratio of enzyme to antibody when either or both may be partially inactivated.

\section{Sensitivity of IEMAs}

The assays detected $0.8 \mathrm{pmol} / \mathrm{l}$ or 20 attomol per well for human insulin and $0.8 \mathrm{pmol} / 1$ or 20 attomol per well for human intact proinsulin (mean +3 standard deviations (SD) of the zero signal). These detection limits were lower than those of the homologous IRMAs, which were $2.3 \mathrm{pmol} / \mathrm{l}$ or 115 attomol per tube and $1.8 \mathrm{pmol} / 1$ or 90 attomol per tube, respectively (6).

Figures 4 and 5 show typical standard curves for IEMA of human insulin and intact proinsulin. In the former assay the cross-reactivities with intact proinsulin and 32-33 split proinsulin were $5 \%$ at concentrations up to $200 \mathrm{pmol} / \mathrm{l}$. In the proinsulin IEMA, the cross-reactivity of insulin was $<1 \%$ and that of $32-33$ split proinsulin was $2.3 \%$ up to $500 \mathrm{pmol} / \mathrm{l}$.

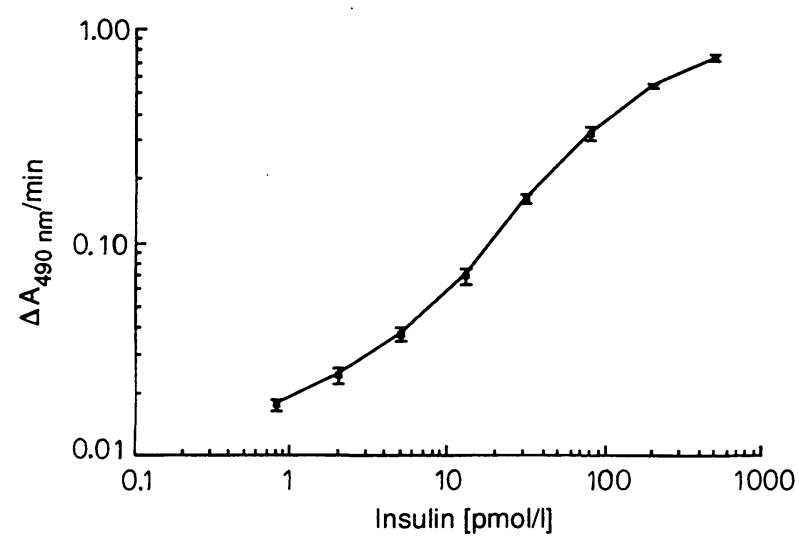

Fig. 4. Log-log representation of the standard curve for IEMA of human insulin. Standard deviations are shown on the graph by the vertical bars. The coefficients of variation were between 2.3 and $9.2 \%$.

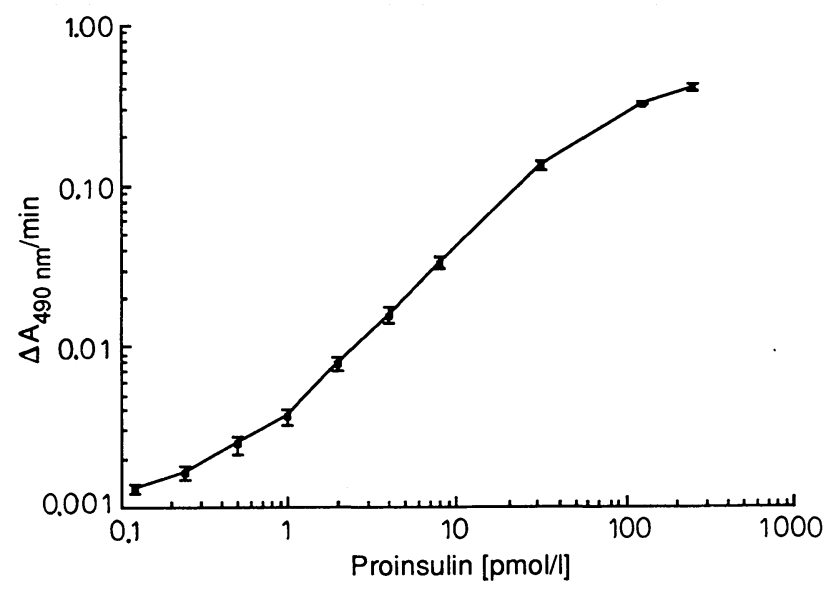

Fig. 5. Log-log representation of the standard curve for IEMA of human intact proinsulin.

Standard deviations are shown on the graph by the vertical bars. The coefficients of variation were between 4.2 and $11.7 \%$. 
We compared the insulin concentrations of 85 plasma samples obtained by IEMA with those obtained by IRMA. The regression equation was (insulin) IEMA $=1.14$ (insulin) IRMA $-3.0, r=0.98$, indicating good agreement between the two methods (fig. 6). Comparison of proinsulin concentrations measured by IEMA with those measured by IRMA also showed acceptable agreement (fig. 7). The regression equation was (proinsulin) IEMA $=1.04$ (proinsulin) IRMA $-0.30, r=0.97, n=115$. Two patients' plasmas gave grossly aberrant proinsulin results by IEMA and by IRMA. In both cases the IEMA proinsulin concentration reverted to the concentration measured by IRMA after incubation with goat antiserum to human IgG, IgA or IgM (Atlantic Antibodies). These plasmas showed considerable non-linearity on serial dilution in $735 \mu \mathrm{mol} / \mathrm{l}$ bovine serum albumin in buffer $\mathrm{F}$ when assayed by IEMA. Increasing the concentration of mouse serum in the reaction mixture and use of a Fab conjugate had no effect on the IEMA result. A screening test based on monoclonal antibody 3B1 for plate coating and as signal antibody detected this nonspecific reaction.

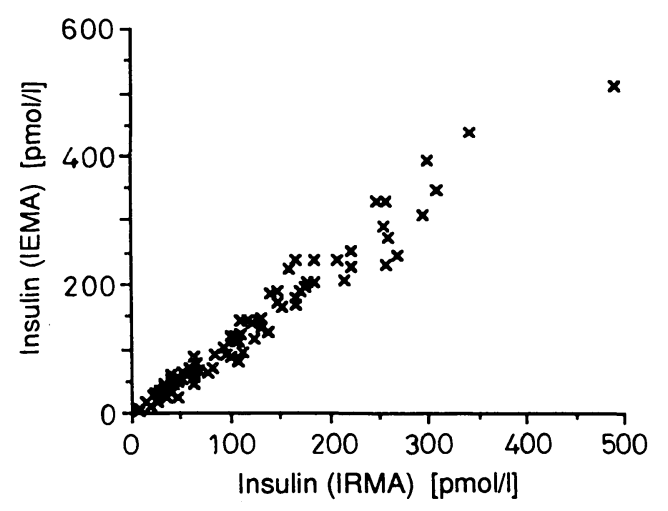

Fig. 6. Comparison of the human insulin concentrations determined by IRMA and IEMA in 85 plasma samples.

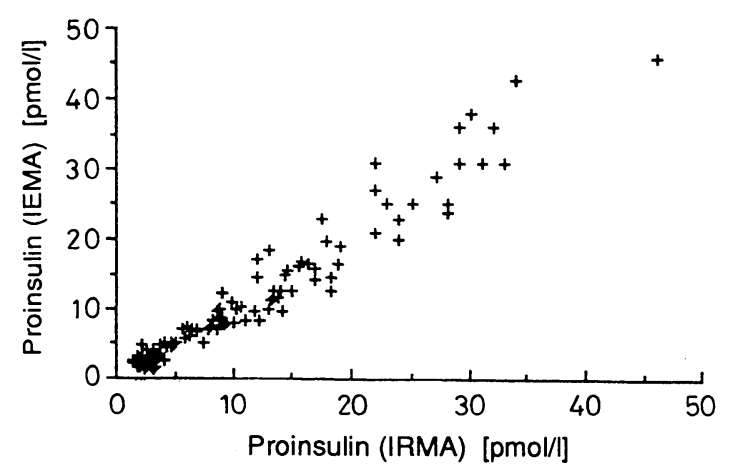

Fig. 7. Comparison of the human proinsulin concentrations determined by IRMA and IEMA in 115 plasma samples.

\section{Precision}

The intra-run variance was tested by assaying four samples twenty times in one assay. The inter-run variance was estimated by analysis of four samples in duplicate in consecutive runs. The reproducibility of these assays was acceptable (tab. 3).

Tab. 3. Reproducibility of the immunoenzymometric assays

\begin{tabular}{|c|c|c|c|}
\hline \multicolumn{4}{|l|}{ Insulin } \\
\hline & $\mathrm{n}$ & $\begin{array}{l}\text { Insulin } \\
(\mathrm{pmol} / \mathrm{l}) \\
(\text { mean } \pm \mathrm{SD})\end{array}$ & $\begin{array}{l}\text { Coefficient of } \\
\text { variation } \\
(\%)\end{array}$ \\
\hline \multicolumn{4}{|l|}{ Within-assay } \\
\hline Sample 1 & 20 & $17 \pm 1.2$ & 6.9 \\
\hline Sample 2 & 20 & $130 \pm 11.8$ & 9.1 \\
\hline Sample 3 & 20 & $308 \pm 37.0$ & 12.0 \\
\hline Sample 4 & 20 & $376 \pm 33.5$ & 8.9 \\
\hline \multicolumn{4}{|c|}{ Between-assay } \\
\hline Sample 5 & 68 & $34 \pm 5.4$ & 14.4 \\
\hline Sample 6 & 58 & $127 \pm 14.4$ & 11.3 \\
\hline Sample 7 & 69 & $254 \pm 27$ & 10.6 \\
\hline Sample 8 & 20 & $386 \pm 52$ & 13.5 \\
\hline \multicolumn{4}{|l|}{ Proinsulin } \\
\hline & $\mathrm{n}$ & $\begin{array}{l}\text { Proinsulin } \\
(\mathrm{pmol} / \mathrm{l}) \\
(\text { mean } \pm \mathrm{SD})\end{array}$ & $\begin{array}{l}\text { Coefficient of } \\
\text { variation } \\
(\%)\end{array}$ \\
\hline \multicolumn{4}{|l|}{ Within-assay } \\
\hline Sample 1 & 17 & $3.4 \pm 0.2$ & 6.3 \\
\hline Sample 2 & 18 & $13.3 \pm 0.5$ & 4.1 \\
\hline Sample 3 & 18 & $55 \pm 1.3$ & 2.3 \\
\hline \multicolumn{4}{|c|}{ Between-assay } \\
\hline Sample 1 & 10 & $3.1 \pm 0.38$ & 12.1 \\
\hline Sample 2 & 11 & $12.2 \pm 1.1$ & 9.2 \\
\hline Sample 3 & 11 & $56 \pm 6.4$ & 11.4 \\
\hline
\end{tabular}

\section{Analytical recovery and dilution}

The recovery of human insulin $(50-200 \mathrm{pmol} / \mathrm{l})$ from plasma, assessed by the addition of known quantities of insulin to plasma, was $99 \%$ (range $96-101 \%$ ). In an experiment carried out with plasma of three normal fed subjects we observed a linear correlation between the degree of dilution (from neat to $1: 16$ ) and the measured concentration. The recovery of human proinsulin $(6-26 \mathrm{pmol} / \mathrm{l})$ from plasma was $98 \%$ (range $88-112 \%$ ). The serial dilution of 5 plasmas containing high concentrations of proinsulin also showed good linearity.

\section{Discussion}

The present results show that the combination of alkaline phosphatase labelling of antibodies with the amplification (cycling) system devised by Johannsson 
et al. (8) is capable of producing insulin and intact proinsulin assays with lower detection limits than those achieved in immunoradiometric assays using the same antibodies. We have found that $10-15$ molecules of the heterobifunctional conjugation reagent $\mathrm{N}$-succinimidyl-3-(2-pyridyldithio)-propionate can be linked to alkaline phosphatase or to a monoclonal antibody before either protein becomes 50\% inactivated. Using a variety of conditions in which the ratios of N-succinimidyl-3-(2-pyridyldithio)-propionate to enzyme or antibody were varied, as well as the ratio of enzyme to antibody, a series of conjugates was prepared with a six fold range of the specific activity of the conjugate. It was observed that the performance of a conjugate in an assay was not simply a function of its specific activity. We have not exhaustively investigated the conditions necessary for optimising the production of conjugates for the assays, though standard curves were produced by conjugates prepared in a variety of ways, suggesting that the overall approach to conjugation is reasonably

\section{References}

1. Sobey, W. J., Beer, S. F., Carrington, C. A., Clark, P. M. S., Frank, B. H., Gray, I. P., Luzio, S. D., Owens, D. R., Schneider, A. E., Siddle, K., Temple, R. C. \& Hales, C. N. (1989) Sensitive and specific two-site immunoradiometric assays for human insulin, proinsulin, 65-66 split and 3233 split proinsulins. Biochem. J. 260, 535-541.

2. Temple, R. C., Carrington, C. A., Luzio, S. D., Owens, D. R., Schneider, A. E., Sobey, W. J. \& Hales, C. N. (1989) Insulin deficiency in non-insulin dependent diabetes. Lancet $i, 293-295$.

3. Avramaes, S., Ternynck, T. \& Guesdon, J. L. (1978) Coupling of enzymes to antibodies and antigens. Scand. J. Immunol. 8 (Suppl. 7), 7-23.

4. Ishikawa, E., Imagawa, M., Hashida, S., Yoshitake, S., Hamaguchi, Y. \& Ueno, T. (1983) Enzyme-labelling of antibodies and their fragments for enzyme immunoassay and immunohistochemical staining. J. Immunoassay 4, $209-327$.

5. Engvall, E. \& Perlmann, P. (1971) Enzyme-linked immunosorbent assay (ELISA). Quantitative assay of immunoglobulin G. Immunochemistry 8, 871-874.

6. Carlsson, J., Drevin, H. \& Axen, R. (1978) Protein thiolation and reversible protein-protein conjugation. Biochem. J. 173, 723-737.

7. Nilsson, P., Bergquist, N. R. \& Grundy, M. S. (1981) A technique for preparing defined conjugates of horseradish peroxide and immunoglobulin. J. Immunol. Methods 41 , $81-93$. robust. Using such conjugates we have developed IEMAs for insulin and for proinsulin, the former having been in routine use for over a year. Further investigations are underway to determine the cause of the discrepant results in the proinsulin assay which may be due to interfering antibodies (14). A simple screening test allows such samples to be identified so that they can be treated by immunoprecipitation before assay. In view of the lower detection limit, longer shelf-life of the labelled antibody and greater ease of automation we believe that such assays are superior to those achieved by direct labelling of monoclonal antibodies with ${ }^{125} \mathrm{I}$.

\section{Acknowledgement}

We thank Annerose Schneider for providing ascites fluid containing the monoclonal antibodies. We also thank Eli Lilly for the iodinated human insulin and intact proinsulin. This work was supported by the French fondation pour la Formation par la Recherche a l'Interface Chimie-Biologie, Paris 75005, France (BA postdoctoral fellowship), by the Medical Research Council (UK) and by the British Diabetic Association.

8. Johannsson, A., Stanley, C. J. \& Self, C. H. (1985) A fast highly sensitive colorimetric enzyme immunoassay system demonstrating benefits of enzyme amplifications in clinical chemistry. Clin. Chim. Acta 148, 119-124.

9. Johannsson, A., Ellis, D. H., Bates, D. L., Plumb, A. M \& Stanley C. J. (1986) Enzyme amplification for immunoassays. Detection limit of one hundredth of an attomole. J. Immunol. Methods 87, 7-11.

10. Bruck, C., Portetelle, D., Glineur, C. \& Bollen, A. (1982) One-step purification of mouse monoclonal antibodies from ascitic fluid by DEAE affigel blue chromotography. J. Immunol. Methods 53, 313-319.

11. Stanker, L. H., Vanderlaan, M. \& Juarez-Salinas, H. (1985) One-step purification of mouse monoclonal antibodies from ascites fluid by hydroxylapatite chromatography. J. Immunol. Methods 76, 157-169.

12. Linhardt, K. \& Walker, K. (1963) Phosphatases (Phosphomonoesterases). In: Methods in Enzymatic Analysis (Bergmeyer, H. U., ed.) Academic Press, New York (2nd edn) pp. $779-787$.

13. Soos, M. \& Siddle, K. (1982) Characterization of monoclonal antibodies directed against human thyroid stimulating hormone. J. Immunol. Methods 51, 57-68.

14. Kohse, K. P. \& Wisser, H. (1990) Antibodies as a source of analytical errors. J. Clin. Chem. Clin. Biochem. 28, $881-$ 892.

Dr. P. M. Clark

Department of Clinical Biochemistry

Addenbrooke's Hospital

Hills Road

Cambridge

CB2 2QR, UK 